\title{
Tilegnelse af boglige kundskaber
}

\author{
Anmeldelse af Mads Hermansen, Copenhagen Business School og Nordiska högskolan för \\ folkhälsovetenskap
}

Tilegnelse af boglige fagkundskaber

Sten Cold Poulsen

MetaConsults Forlag. Slagelse

2006

300 sider

ISBN: 87-610-0077-9

Sten Clod har været i feltet om udvikling, læring og facilitering $i$ en hel menneskealder. Den aktuelle bog er en ud af tre planlagte, hvor forgængeren 'Målstyret kompetenceudvikling i undervisning og læring' fra 2002 var den første, og en planlagt om 'Den anden lærelærerplan' er under skrivning.

I bogen beskæftiger Sten Clod sig, som titlen understreger, med den boglige tilegnelse. En sympatisk aspiration at kaste sig over et komplekst og sammenfiltret område for at søge at rede trådene ud, så det ikke alene for forfatteren giver mere klarhed (ved at skrive bogen), men også for læseren giver oversigt og udkigspunkter til ordning.

Bogen falder $i$ tre tydelige dele. Begrundelser og overvejelser over det at tilegne sig boglige fagkundskaber, hukommelse og boglig læring og endelig en model (af taksonomisk tilsnit) over faser i oparbejdelse af boglige fagkundskaber.

Bogen er på mange måder et forsøg på at revitalisere en række af de begrundelser for at lave undervisning, som af forskellige grunde er blevet forladt, men ikke burde være det, fx træning, udenadslære m.v. I Sten Clods udgave dog tydeligt argumenteret for og italesat $i$ en ramme af sammenhæng og mening. Altså et sympatisk projekt.

Bogen bærer præg af, at første formål (at skabe forfatterklarhed) har været forfulgt. Der lyder næsten et lettelsens suk i epilogen på side $270 \mathrm{om}$, at bogen nu er ved at være afsluttet og kan sendes til trykning. Således får Sten Clod mere end antydet, at det er det lystfyldte, besværlige mak med sagen, som har drevet værket, men kommer således også paradoksalt til at negere en del af sit budskab om, at det ikke altid kan være lysten, der driver værket, men netop alle mulige andre forhold.

Et af de temaer, som Sten Clod forholder sig til, er læringsstil. Det får kun en kort omtale og mest i den udgave, som forfatterparret Dunn \& Dunn (som der så i øvrigt ikke er litteraturhenvisning til) har beskrevet med relevante identificeringer af, hvordan vi er mere eller mindre orienterede på forskellige perceptionskanaler fx det auditive eller det visuelle. Imidlertid forbigår Sten Clod de relevante stilovervejelser, som fx D. Kolb eller R. Sternberg har gjort sig. Specielt Sternberg er i denne sammenhæng interessant. Han præsenterer en teori, som i tretten dimensioner identificerer, hvordan vi bedst kobler os på. Bl.a. opererer han med:

Funktionen, stilens overordnede opgave: 'den lovgivende' (den, der selv helst vil lave sit system til ordning), 'den udøvende' (den, der helst vil følge forudgivne procedurer) og 'den dømmende' (den, der helst vil forholde sig til noget eller nogen på en vurderende måde).

Formen henviser til den måde, stilen sætter sig igennem hos den enkelte. Man kan godt kalde det den måde, personen prioriterer sine arbejdsopgaver og vælger rækkefølge på. Sternberg taler om fire former for stil:'Den monarkiske', 'den hierarkiske', 'den oligarkiske' og 'den anarkiske' stil. Den monarkiske tænkningsstil henviser til det forhold, hvor personen har præference for at arbejde med én sag ad gangen. Bæreren af den hierarkiske stil tilrettelægger sig med en ordning og prioritering af opgaverne, før vedkommende går i gang med de vigtigste. Det oligarkiske menneske vælger at arbejde parallelt med mange ting på én gang, og endelig er der det anarkiske, som ordner sig mere associativt og tilfældigt med arbejdsopgaverne.

Niveauer. Her arbejdes der med to: Globalt og lokalt. Hvor det globale henviser til den stil, hvor der er tendens til overordning og generalisering af synsvinkel. Det lokale henviser til en tendens til at arbejde med interessante elementer af helheden uden særlig interesse for sammenhæng.

Virkefelter. Intern og ekstern stil. Den interne orienterer sig overvejende mod egne begrundelser og fortolkninger, mens den eksterne er orienteret mod at undersøge omgivelsernes synspunkter for at lade dem influere på egne meninger.

Indstillinger. Her refereres der igen til to stile: Liberal 
og konservativ. Det liberale henviser til en åbnende og eksperimenterende stil, mens konservativ stil henviser til præference for at bruge velkendte og afprøvede måder at gøre tingene på.

Hvis man vover at sætte Sten Clods bog ind i denne matrix, er mit bud, at den er drevet af 'udøvelse' kombineret med 'dømmende'. Den er 'oligarkisk', den er 'lokal', 'ekstern' og 'konservativ'.

I den korte udgave betyder det, at vi făr en bog, som eksponerer Sten Clods eget system og derfor må afvise at bruge andres systemer til at sætte overvejelserne ind i. Han er altså nødt til at lave sit eget system (derfor får vi også en alt for lang bog).

Bogen bliver 'dømmende', da den er meget normativ og foreskrivende i, hvad der er og burde være (derfor er der også tendens til, på trods af stor belæsthed, at konklusioner bliver af den lidt udskældende art, hvor forfatteren ved bedst).

Bogen bliver oligarkisk, idet vi uden noget eksplicit og klart ordningssystem får mange ting i feltet på en gang uden at han for alvor gør noget til over- eller underordningsforhold, ja nogen gange identificeres fænomener på meget forskellige niveauer som del af samme forhold. Her får vi i tur og orden præsenteret det, som Sten Clod har været inde om i sit forsøg på at få overblik over feltet. Sågar fyldes mange sider med, hvad læring ikke er. Hvis den positive definition var blevet kørt til ende, behøvede han ikke at folde den meget omstændelige negative definition ud i livet. Der bliver ikke ordnet, sorteret eller betydningsgjort.

Bogen er ekstern, fordi ambitionen er at sammenfatte alt det, der nu findes, med det, som forfatteren selv har fundet relevant.

Og endelig er bogen 'konservativ', fordi argumentationen er orienteret meget mod at revitalisere de gode dyder, som vi af mere eller mindre gode grunde har fået afskrevet, men som altså burde inddrages igen. Dette gør, at vi ind imellem får ramsaltet og relevant argumentation for revitalisering af gamle dyder ( $\mathrm{fx}$ at lære, så det er så lært, at det ligner overindlæring).

Alt $i$ alt făr vi en bog, som generøst breder et meget problematisk felt ud, så man selv kan gå på arkæologisk opdagelse. For dem som ønsker et bud, som mest er ordnet normativt, er bogen en gave, fordi den så insisterende forsøger at brede felter ud, som den ikke absolut havde behøvet. Disse felter er selvindlysende, fx begrundelserne for taksonomiske overvejelser, hvor vi i universitetsundervisningen i lyset af den nye karakterskala knyttet til fagmål i den grad har været nødt til at have snuden i sporet i udformning af taksonomiske fagmål i studieordningerne. I diskussion af forholdet viden, kvalifikationer og kompetencer må det også siges, at vi blive præsenteret for en meget minutiøs diskussion og præsentation af stof, som allerede er integreret og indarbejdet i gængse forståelser.
Hvis man vil have en revitalisering af grundlaget for undervisning i boglige registre og synes det er fint, at vi ind imellem stopper så meget op i de refleksioner, som netop har optaget Sten Clod, er bogen imidlertid god, ja næsten så god, at den kunne fungere som opslagsbog for de begreber, som mere eller mindre fritflydende præger feltet. Hvis denne funktion imidlertid skulle have været helt på niveau, skulle der ud over en ret udmærket og detaljeret ordliste også have været en detaljeret indholdsfortegnelse foran i bogen og et stikordsregister at orientere sig efter.

Denne anmeldelse kan læses som en anmelderens stil, der møder og forundres over forfatterens stil, indspundet i egen stil. Sådan er det naturligvis. Så når jeg siger, at det ville have været herligt, om Sten Clod havde nedkogt mangfoldigheden til nogle modelovervejelser, hvor de mange sammenfald, der er på de begreber, hvormed vi prover at fange feltets mangfoldighed, kunne være allokeret til modeller i et mere forenklet univers, er det udtryk for min stil. Jeg vil nu alligevel fremture et øjeblik mere, fordi jeg også tror, det ville have tilført kvaliteter, hvis bogen var blevet mere ordnet og minimalistisk. Et eksempel på en akse i en model, som kunne ordne feltet mere overordnet, er udspændtheden mellem induktiv og deduktiv undervisning. Hvad gør det ved iagttagelsen, at man taler om at gå mod det generaliserende fra en eksemplificerende position eller omvendt?

En stor forskel efter min mening, hvor den store skødesynd i universitetspædagogik har været en hoven opfattelse af, at man fint kunne begynde undervisning med at introducere til teorien, og så i øvrigt overlade det til de studerendes egen sociologiske fantasi at eksemplificere den teoretiske position.

Men bortset fra de ind imellem lidt knubbede ord, så læs bogen. Der er rigtig meget stof $i$ den. Derfor også rigtig mange anledninger til at tænke om det, man gør.

\section{Litteratur}

Dunn, R., \& Dunn, K. (1998). The complete guide to the learning styles inservice system. Prentice Hall.

Kolb, A.Y., \& Kolb, D.A. (2005). Learning style and learning space. Enhancing experimental learning in higher education. Academy of Management Learning and Education, 4(2) (p. 193-212).

Sternberg, R. (2001). Måder at tonke på-tonkningens stil. Århus: Forlaget Klim. 